\title{
Variation of salinity and nitrogen concentration affects the pentacyclic triterpenoid inventory of the haloalkaliphilic aerobic methanotrophic bacterium Methylotuvimicrobium alcaliphilum
}

\author{
Alexmar Cordova-Gonzalez ${ }^{1} \cdot$ Daniel Birgel $^{1} \cdot$ Andreas Kappler $^{2} \cdot$ Jörn Peckmann $^{1}$
}

Received: 18 November 2020 / Accepted: 1 April 2021 / Published online: 18 April 2021

(c) The Author(s) 2021

\begin{abstract}
The occurrence and activity of aerobic methanotrophs are influenced by environmental conditions, including pH, temperature, salinity, methane and oxygen concentrations, and nutrient availability. Aerobic methanotrophs synthesize a variety of lipids important for cell functions. However, culture-based experiments studying the influence of environmental parameters on lipid production by aerobic methanotrophs are scarce. Such information is crucial to interpret lipid patterns of methanotrophic bacteria in the environment. In this study, the alkaliphilic strain Methylotuvimicrobium alcaliphilum was cultivated under different salinities and different nitrate concentrations to assess the effect of changing conditions on the inventory of pentacyclic triterpenoids. The results indicate that hopanoid abundance is enhanced at lower salinity and higher nitrate concentration. The production of most pentacyclic triterpenoids was favored at low salinity, especially for aminotriol. Interestingly, 3-methyl-aminotetrol and tetrahymanol were favored at higher salinity. Bacteriohopanepolyols (BHPs), particularly aminotriol and 3-methyl-aminotriol, increased considerably at higher nitrate concentrations. Four novel $N$-containing BHPs - aminodiol, 3-methyl-aminodiol, and isomers of aminotriol and 3-methyl-aminotriol—were identified. This study highlights the significance of environmental factors for bacterial lipid production and documents the need for cultivation studies under variable conditions to utilize the full potential of the biomarker concept.
\end{abstract}

Keywords Aerobic methanotrophs $\cdot$ Nitrate $\cdot$ Salinity $\cdot$ Pentacyclic triterpenoids $\cdot$ Bacteriohopanepolyols $\cdot$ Tetrahymanol

\section{Introduction}

Aerobic methanotrophic bacteria are an important methane sink due to their ability to utilize methane as the sole carbon and energy source, using the key enzyme monooxygenase (Hanson and Hanson 1996; Semrau et al. 2010). Bacterial aerobic methane oxidation (MOx) contributes significantly to the withdrawal of methane released from anoxic sediments and soils, which otherwise could accumulate in the atmosphere as a severe greenhouse gas. Therefore, MOx is

Communicated by M. Moracci.

Daniel Birgel

daniel.birgel@uni-hamburg.de

1 Institut für Geologie, Centrum für Erdsystemforschung und Nachhaltigkeit, Universität Hamburg, Hamburg, Germany

2 Geomikrobiologie, Zentrum für Angewandte Geowissenschaften, Universität Tübingen, Tübingen, Germany essential for methane consumption (Hanson and Hanson 1996; Sherry et al. 2016). Aerobic methanotrophs occur in terrestrial, freshwater, and marine ecosystems, preferably at oxic-anoxic interfaces. Aerobic methanotrophic bacteria are microaerophilic, using oxygen as electron acceptor and methane as carbon and energy source (Boetius and Wenzhöfer 2013; Bessette et al. 2017). Generally, aerobic methanotrophs are divided into two major groups, belonging to the Gammaproteobacteria (Type I and Type X methanotrophs) and Alphaproteobacteria (Type II methanotrophs), which differ in physiology, chemotaxonomy, internal ultrastructure, carbon assimilation pathways, and other biochemical aspects (Bowman 2006).

Type II methanotrophic bacteria are restricted to terrestrial environments such as peats, soils, and lakes. Type I methanotrophic bacteria are more versatile, also dwelling in the marine realm (e.g., Knief 2015). Generally, the occurrence and activity of aerobic methanotrophic bacteria are influenced by environmental conditions, including $\mathrm{pH}$, temperature, salinity, methane and oxygen concentrations, 
and nutrient availability (Semrau et al. 2010; Knief 2015; Sherry et al. 2016). Among these factors, the effect of inorganic nitrogen on aerobic methanotrophs has been widely studied, particularly for agricultural soils, where ammonium- or nitrate-based fertilizers may influence methane oxidation and affect the global methane budget (Noll et al. 2008). Unfortunately, results of culture studies on the effect of inorganic nitrogen addition on methanotrophic activity are not in agreement with reports demonstrating either inhibition (Dunfield and Knowles 1995) or stimulation (Bodelier et al. 2000; Bodelier and Laanbroek 2004) of methane oxidation. Although the link between nitrogen availability and methane consumption is still unclear, it is assumed that the effect of nitrogen is dependent on the structure of the in situ methanotrophic community (Hoefman et al. 2014), since aerobic methanotrophs have shown metabolic variability regarding nitrogen assimilation on both genus and species level. The nitrogen metabolism of various aerobic methanotrophs strains is diverse, including cometabolic oxidation of ammonia (Nyerges and Stein 2009), nitrate reduction to nitrite (Bowman et al. 1993), detoxification of hydroxylamine and nitrite (Nyerges and Stein 2009; Nyerges et al. 2010), and fixation of atmospheric nitrogen, the latter known from few strains only (Hoefman et al. 2014; Tays et al. 2018). Among the various genera of aerobic methanotrophs, the nitrogen metabolism seems to be strain-specific (Hoefman et al. 2014). Nonetheless, gammaproteobacterial methanotrophs are preferentially stimulated by nitrogen amendments (Bodelier et al. 2000) and alphaproteobacterial methanotrophs cope better with nitrogen limitation than Gammaproteobacteria, perhaps due to their ability to fix dinitrogen (Nyerges and Stein 2009).

Another important factor influencing the activity of aerobic methanotrophs is salinity. Sherry et al. (2016) analyzed the response of a methanotroph community in estuarine sediments to salinity change and documented an inverse correlation of decreasing methane oxidation rates with increasing salinity. MOx communities at salinities higher than $35 \mathrm{~g} / 1$ were dominated by Type I Methylomicrobium species, closely related to the halo-/alkalitolerant methanotroph Methylotuvimicrobium alcaliphilum, which lives at normal marine and higher salinities (Orata et al. 2018). Intriguingly, none of the sequences identified were affiliated with known marine methanotrophs (Sherry et al. 2016).

Among the most specific capabilities of aerobic methanotrophs is their ability to synthesize a unique lipid biomarker inventory. Apart from fatty acids with characteristic double bond positions (e.g., Hanson and Hanson 1996), this group of bacteria is known as a producer of a variety of source-specific pentacyclic (hopanoids) and tetracyclic triterpenoids (steroids) (e.g., Bouvier et al. 1976; Rohmer et al. 1984; Talbot and Farrimond 2007; Banta et al. 2015; Rush et al. 2016; Wei et al. 2016; Cordova-Gonzalez et al.
2020). The cyclic triterpenoids are known to be crucial for cell functions such as cell growth and survival (Kannenberg and Poralla 1999; Welander et al. 2009; Welander and Summons 2012). Aerobic methanotrophs are among the few bacteria capable to express their ability to produce significant amounts of 3-methyl hopanoids (Welander and Summons 2012) and bacteriohopanepolyols (BHPs) with terminal amino groups and three to five hydroxyl groups (amino BHPs), or a combination of both (Zundel and Rohmer 1985; Talbot et al. 2003). Amino BHPs are used by aerobic methanotrophs to cope with environmental stress (Welander and Summons 2012; Kulkarni et al. 2013). Previous studies have investigated the influence of temperature, $\mathrm{pH}$, and nitrogen metabolism on bacterial hopanoid production. For example, contents of BHPs in Bacillus acidocaldarius, a thermoacidophilic bacterium, increased with increasing temperature, but only moderately with decreasing $\mathrm{pH}$ (Poralla et al. 1984), while a psychrotolerant strain of the aerobic methanotroph Methylomonas methanica revealed an opposite trend with respect to temperature, showing a decrease of hopanoid contents with increasing temperature (Jahnke et al. 1999). Strains of Methylovulum psychrotolerans, an aerobic psychrotolerant methanotroph, also showed a decrease in hopanol contents, specifically tetrafunctionalized BHPs and diplopterol, with increasing temperature, along with an increase in penta- and hexafunctionalized BHPs (Bale et al. 2019). Osborne et al. (2017) have studied the effect of varying temperatures on BHP production in a sedimentary methanotrophic community from the environment. These authors demonstrated a temperature dependence of aminopentol production, but not for aminotetrol or aminotriol. Nalin et al. (2000) have reported slightly increased hopanoid contents under nitrogen-replete $\left(\mathrm{NH}_{4}^{+}\right)$conditions for several nitrogen-fixing actinomycete Frankia strains. Even though some studies exist, our knowledge on the influence of environmental parameters on lipid production by methanotrophic bacteria is still limited, being based on only a few culture experiments (Jahnke et al. 1999; Talbot et al. 2001; Cordova-Gonzalez et al. 2020). Often the interpretation of environmental samples is still challenging due to the lack of culture experiments under conditions close to those of the respective environments. More cultivation experiments are needed to evaluate possible unknown adaptations of aerobic methanotrophs strains in response to changing environmental conditions. Complementarily, experiments using uncultured strains in micro- and mesocosms (Sherry et al. 2016; Osborne et al. 2017) need to be performed to close the gap between the biomarker patterns of cultures and environmental samples.

Here, we use cultivation experiments to assess whether changes in nitrate availability and salinity affect the composition and abundance of pentacyclic triterpenoids produced by the Type I methanotroph Methylotuvimicrobium 
alcaliphilum, a haloalkaliphilic strain, which has been studied previously for its triterpenoid inventory (Banta et al. 2015; Rush et al. 2016; Cordova-Gonzalez et al. 2020). We report the occurrence of novel BHPs in M. alcaliphilum and modifications of its lipid inventory at varying salinities and nitrate concentrations. This approach will help to understand the limitations of aerobic methanotrophy in haloalkaline environments and will foster interpretation of biomarker patterns observed in the environment and the rock record.

\section{Materials and methods}

Methylomicrobium alcaliphilum $20 \mathrm{Z}$ (now Methylotuvimicrobium alcaliphilum; Orata et al. 2018) strain was obtained from the Leibniz Institute DSMZ-German Collection of Microorganisms and Cell Cultures. The cultivation experiments were performed in the Geomicrobiology group at the University of Tübingen, Germany. M. alcaliphilum was first isolated from surface sediments of highly alkaline soda lakes in Russia (Kalyuzhnaya et al. 2008).

\section{Culture conditions}

M. alcaliphilum strains were grown in $100 \mathrm{ml}$ serum bottles filled with $10 \mathrm{ml}$ of the DSMZ recommended Methylomicrobium medium (DSMZ 1180) containing $30 \mathrm{~g} \mathrm{NaCl}, 0.20 \mathrm{~g}$ $\mathrm{MgSO}_{4} \times 7 \mathrm{H}_{2} \mathrm{O}, 0.02 \mathrm{~g} \mathrm{CaCl}_{2} \times 2 \mathrm{H}_{2} \mathrm{O}$ and $1 \mathrm{~g} \mathrm{KNO}_{3}$, in $1000 \mathrm{ml}$ distilled water. The $\mathrm{pH}$ was adjusted to 8.5 and cultures were incubated at $28{ }^{\circ} \mathrm{C}$ and shaken at $200 \mathrm{rpm}$. The initial gas-mixing ratio was adjusted at methane:air 1:1 $(v / v)$. Four different culture conditions were applied: standard growth conditions $\left(3 \% \mathrm{NaCl}, 0.1 \%\right.$ or $10 \mathrm{mM} \mathrm{KNO}_{3}$ ), low salinity $(1 \% \mathrm{NaCl})$, high salinity $(8.7 \% \mathrm{NaCl})$, and high nitrate concentration $\left(1 \%\right.$ or $\left.100 \mathrm{mM} \mathrm{KNO}{ }_{3}\right)$. Cells were harvested by centrifugation at $4000 \mathrm{rpm}$ for $10 \mathrm{~min}$ when entering the stationary phase and freeze-dried for further analyses. Cell growth was monitored by measuring the optical density at $600 \mathrm{~nm}$ on a Thermo Scientific Multiskan Go spectrophotometer.

\section{Extraction and derivatization}

Harvested cells were freeze-dried and gently ground, then extracted with dichloromethane (DCM)/methanol $(\mathrm{MeOH})$ $(3: 1, v / v)$ by successive ultrasonication to produce the total lipid extract (TLE) according to Cordova-Gonzalez et al. (2020). An aliquot of the TLE was acetylated by adding acetic acid anhydride/pyridine $(1: 1 v / v)$ to the dried TLE at $60{ }^{\circ} \mathrm{C}$ for one hour and left at room temperature overnight. The solvent mixture was carefully dried with a gentle stream of $\mathrm{N}_{2}$. Hopanoids with $\leq 30$ carbons and tetrahymanol were measured by gas chromatography-flame ionization detector (GC-FID) and coupled gas chromatography-mass spectrometry (GC-MS). For analysis of BHPs, the acetylated aliquots of TLE were measured by means of highperformance liquid chromatography-mass spectrometry (HPLC-MS). Tetrafunctionalized BHPs (aminotriols) were additionally measured on GC-MS with a high temperature column (see section "Gas chromatography and highperformance liquid chromatography"). A second aliquot of the underivatized TLE was treated with periodic acid and sodium boron hydride to transform BHPs in GC-amenable hopanols (Rohmer et al. 1984). Briefly, after periodic acid cleavage, tetrafunctionalized BHPs (e.g., aminotriol and bacteriohopanetetrol) were converted to $\mathrm{C}_{32} 17 \beta(\mathrm{H}), 21 \beta(\mathrm{H})$ hopanol (bishomohopanol), pentafunctionalized BHPs (e.g., aminotetrol and bacteriohopanepentol) produce $\mathrm{C}_{31}$ $17 \beta(\mathrm{H}), 21 \beta(\mathrm{H})$-hopanol (homohopanol), and hexafunctionalized BHPs (e.g., aminopentol) yield $\mathrm{C}_{30} 17 \beta(\mathrm{H}), 21 \beta(\mathrm{H})$ hopanol (hopanol). The resulting hopanols were acetylated as described above.

\section{Gas chromatography and high-performance liquid chromatography}

The acetylated TLEs were analyzed by GC-FID for quantification, using a Thermo Scientific Trace 1300 Series, and by GC-MS for identification, using a Thermo Scientific Trace GC Ultra coupled to a Thermo Scientific DSQ II mass spectrometer at the University of Hamburg, Germany. A programmed temperature vaporizer (PTV) was used for injection in both devices, the carrier gases were hydrogen for GC-FID and helium for GC-MS. Compounds were separated using an Agilent HP-5 MS UI fused silica capillary column ( $30 \mathrm{~m}$ length, $0.25 \mathrm{~mm}$ i.d., $0.25 \mu \mathrm{m}$ film thickness). The $\mathrm{GC}$ temperature program was $50{ }^{\circ} \mathrm{C}(3 \mathrm{~min})$ to $230{ }^{\circ} \mathrm{C}$ at $15{ }^{\circ} \mathrm{C} / \min (2 \mathrm{~min}), 230-325^{\circ} \mathrm{C}$ at $6{ }^{\circ} \mathrm{C} / \mathrm{min}$, $25 \mathrm{~min}$ isothermal. The identification by $\mathrm{GC}-\mathrm{MS}$ was based on GC retention times and comparison of mass spectra with published data. Internal standards (1-nonadecanol and $5 \alpha$-cholestane) with known concentrations were added prior to extraction for quantification. BHPs were analyzed as their BHP-cleaved hopanols under the same conditions. High temperature gas chromatography coupled with mass spectrometry (HTGC-MS) was performed on the same machines using a Zebron ZB-5HT capillary column (15 m length, $0.32 \mathrm{~mm}$ i.d., $0.10 \mu \mathrm{m}$ film thickness). The GC temperature program was $50{ }^{\circ} \mathrm{C}(3 \mathrm{~min})$ to $260{ }^{\circ} \mathrm{C}$ at $15^{\circ} \mathrm{C} / \mathrm{min}$ (0 min), $260-350{ }^{\circ} \mathrm{C}$ at $10^{\circ} \mathrm{C} / \mathrm{min}, 30 \mathrm{~min}$ isothermal.

High-performance liquid chromatography-mass spectrometry (HPLC-MS) analyses were performed using a Varian MS Workstation 6.91 HPLC system coupled to a Varian 1200L triple quadrupole mass spectrometer, equipped with a reversed-phase Phenomenex Kinetex ${ }^{\circledR}$ EVO $C_{18} 100 \AA$ column (150 mm length, $2.1 \mathrm{~mm}$ i.d., $2.6 \mu \mathrm{m}$ particle size) 
and a security guard column cartridge of the same material. The program used was $0.14 \mathrm{ml} / \mathrm{min}$ at $35^{\circ} \mathrm{C}$ with $100 \%$ $A(0-3 \mathrm{~min})$ to $100 \% \mathrm{~B}$ (at $30 \mathrm{~min}$ ); isocratic (to $40 \mathrm{~min}$ ), returning to starting conditions over $5 \mathrm{~min}$ and stabilizing for $5 \mathrm{~min}$ (where $A=90 \% \mathrm{MeOH} / 10 \%$ water and $B=59 \%$ $\mathrm{MeOH} / 40 \%$ propan-2-ol/1\% water). The MS instrument was equipped with an atmospheric pressure chemical ionization (APCI) source operated in positive ion mode. The detection was achieved at a peak width of $1.0 \mathrm{amu}$ (scan time $2.5 \mathrm{~s}$ ) and the mass scan range was set to $m / z, 200-1200$. The acetylated extracts were injected in $\mathrm{MeOH} /$ propan-2-ol (3:2 $v / v)$ and a known amount of internal standard (5 $\alpha$-pregnane$3 \beta, 17 \beta, 20 \beta$-triol) was added prior to analysis for a semiquantitative estimate of the concentration of BHPs. Compounds were identified by comparison with published data and relative retention time. To verify the elution time of the regular aminotriol, peaks in the samples were compared with those in samples of Desulfovibrio strains (Blumenberg et al. 2006), run at the same conditions.

BHPs were measured as intact BHPs by means of HPLC-MS and as periodic acid cleavage products (Fig. 1a, b). GC-MS analyses of periodic acid cleavage products (Fig. 1) showed a considerably higher contribution of aminotetrol (V; see Appendix for roman numbers) and 3-methylaminotetrol (VI) than in HPLC-MS, suggesting and underestimation in the latter technique. In general, tetrafunctionalized BHPs (aminotriols III and 3-methyl-aminotriols IV) were more abundant in LC-MS measurements than in
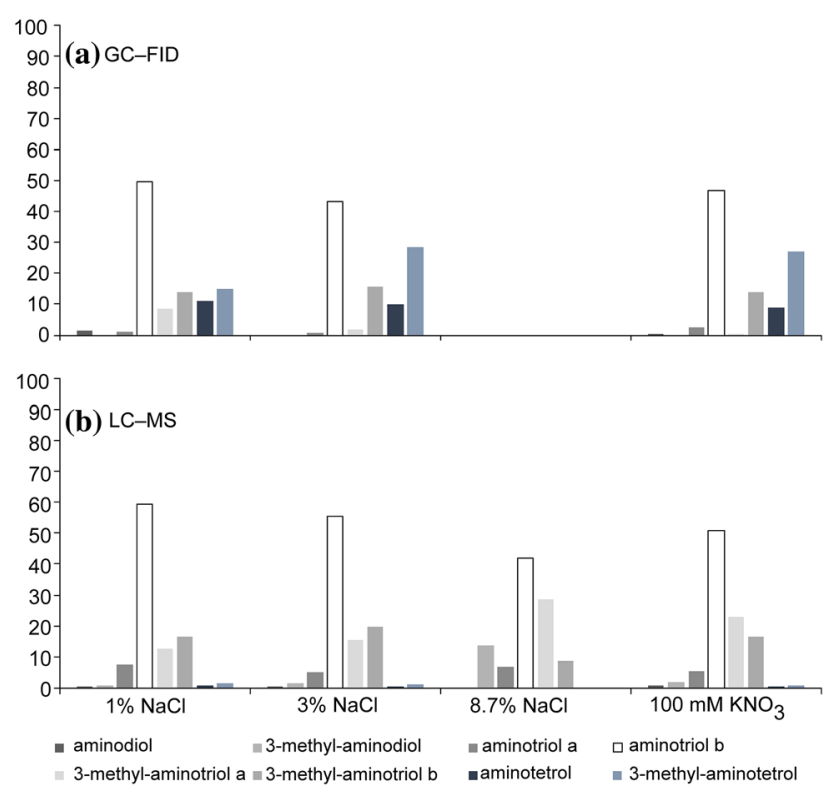

Fig. 1 Comparison of quantification of BHPs of M. alcaliphilum as a hopanol products after periodic acid cleavage using GC-FID and b intact hopanols using LC-MS reflecting different salinities and nitrate concentration. GC-FID data for experiments at $8.7 \% \mathrm{NaCl}$ are not shown
GC-FID measurements of the respective hopanol products. Pentafunctionalized BHPs (aminotetrol $\mathbf{V}$ and 3-methylaminotetrol VI) were less abundant in LC-MS measurements than their corresponding hopanol products measured by GC-FID. Similar discrepancies have been reported for tetrafunctionalized BHPs by van Winden (2011) and were attributed either to underestimation of pentafunctionalized compounds due to LC-MS response factors or to oversight of unknown pentafunctionalized BHPs in the LC-MS analyses. Other studies have shown that BHP contents measured with HPLC-MS are 50-100\% higher than those measured with GC-FID (Sessions et al. 2013), although the reasons remain unclear. In view of these discrepancies, the BHP contents are reported herein as their periodic acid cleavage products only. Moreover, since standards were not available for each functionalized hopanoid, quantification of BHPs with HPLC-MS could introduce a large error, while GC-FID provides the most accurate quantitation assuming a uniform response factor (Jorgensen et al. 1990), particularly for compounds within the same class.

\section{Results and discussion}

\section{Novel $\mathrm{N}$-containing BHPs}

The inventory of lipid biomarkers of the Type I methanotroph $M$. alcaliphilum has been previously described by Banta et al. (2015), Rush et al. (2016), and Cordova-Gonzalez et al. (2020), although under different culturing conditions than those chosen in this study. Most abundant BHPs in M. alcaliphilum cultures are aminotriol (IIIb), 3-methylaminotriol (IVb), aminotetrol (V), and 3-methyl-aminotetrol (VI; Figs. 2, 3).

In addition to the amino-BHPs previously reported for M. alcaliphilum (IIIb, IVb, V, and VI; Figs. 2, 3), the HPLC-MS analysis revealed the presence of four novel components with base peaks at $m / z 656$ (acetylated; BHP656 I), $\mathrm{m} / z 670$ (acetylated; BHP-670 II), $\mathrm{m} / z 714$ (IIIa) and $m / z 728$ (IVa), respectively $\left([\mathrm{M}+\mathrm{H}]^{+}\right.$; Figs. 2, 3). These compounds are tentatively identified as novel $N$-containing BHPs on the basis of the even $m / z$ value of the base peak ion (cf. Talbot et al. 2016).

The LC mass spectrum of BHP-656 (I; Fig. 3a) includes a minor peak at $\mathrm{m} / \mathrm{z} 596$, indicating a loss of $60 \mathrm{Da}$ (i.e., acetylated $\mathrm{OH}$ group, $\mathrm{CH}_{3} \mathrm{COOH}$ ). Compound BHP-656 I elutes later than aminotriol IIIb, suggesting a less polar compound on the reversed-phase HPLC column (see section "Gas chromatography and high-performance liquid chromatography"). The peak in question was tentatively identified as aminodiol. Directly after BHP-656 I elutes the compound BHP-670 II. The mass spectrum of BHP-670 II (Fig. 3b) includes other minor peaks at $m / z 610$ and $m / z 568$, indicating a neutral loss 


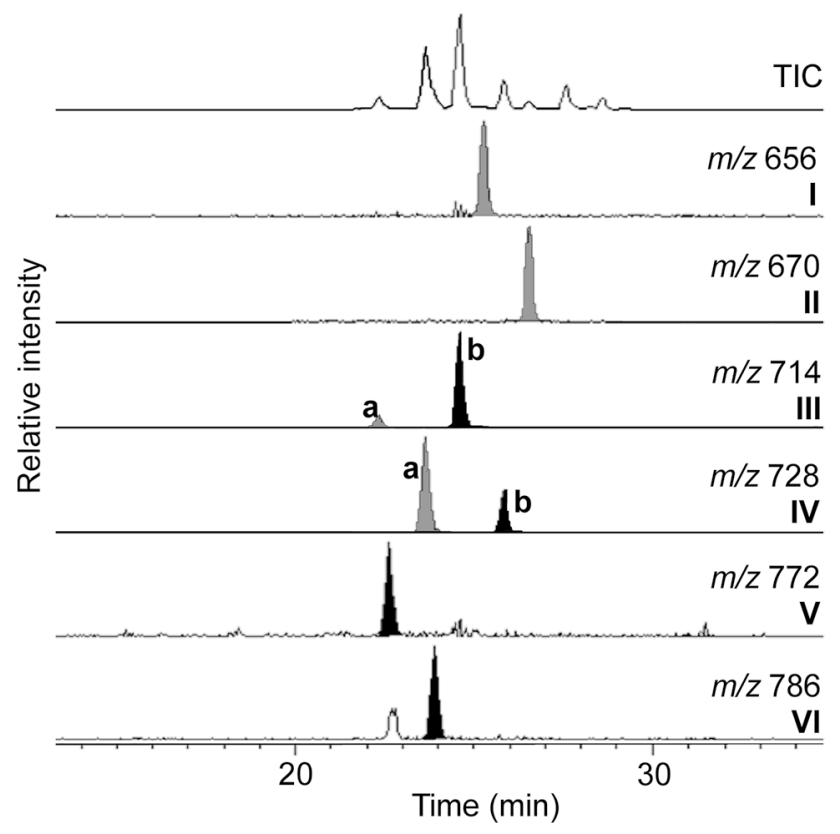

Fig. 2 Partial HPLC-MS chromatograms (13-35 min) showing BHPs in the acetylated total lipid extract of $M$. alcaliphilum grown at 3\% salinity and $100 \mathrm{mM} \mathrm{KNO}_{3}$. Novel BHPs are indicated in gray

of $60 \mathrm{Da}$ (i.e., acetylated $\mathrm{OH}$ group, $\mathrm{CH}_{3} \mathrm{COOH}$ ) followed by a neutral loss of $42 \mathrm{Da}$ (i.e., partial loss of acetylated $\mathrm{OH}$ group, $\mathrm{COCH}_{2}$ ), respectively. The $14 \mathrm{Da}$ difference suggests non-methylated (I) and methylated (II) homologues, with the presence of a methyl group at C-3 in the latter, since methylation at this position is typical of Type I methanotrophs (Talbot et al. 2003).

As mentioned above, two new peaks with $\mathrm{m} / \mathrm{z} 714$ (IIIa) and $m / z 728$ (IVa) were identified, respectively. Both peaks IIIa and IVa were eluting earlier than the commonly found BHPs aminotriol IIIb and 3-methyl-aminotriol IVb, respectively (see Fig. 2). The mass spectrum of $\mathrm{m} / \mathrm{z}, 714$ IIIa (Fig. 3c) is almost identical to the mass spectrum of regular aminotriol IIIb (Fig. 3d) with $\left([\mathrm{M}+\mathrm{H}]^{+}=m / z, 714\right.$ and minor peaks at $\mathrm{m} / \mathrm{z} 654, \mathrm{~m} / \mathrm{z} 612$ and $\mathrm{m} / \mathrm{z} 552$ representing neutral losses of $60 \mathrm{Da}$ (i.e., acetylated $\mathrm{OH}$ group) followed by losses of $42 \mathrm{Da}$ (i.e., loss of partial fragment of acetylated $\mathrm{OH}$ group) and $60 \mathrm{Da}$, respectively. However, the peak at $\mathrm{m} / z$ $552\left(\left[\mathrm{M}+\mathrm{H}-2 \mathrm{CH}_{3} \mathrm{COOH}-\mathrm{COCH}_{2}\right]^{+}\right)$in the MS spectrum of compound IIIa is less prominent than in the MS spectrum of regular aminotriol IIIb and the association ion at $m / z, 774$ $\left([\mathrm{M}+\mathrm{H}+60]^{+}\right)$(sensu Talbot et al. 2001) is absent.

Analogous to $m / z, 714$ peaks, the spectrum of $m / z 728$ IVa (Fig. 3e) is similar to the mass spectrum of regular 3-methyl-aminotriol IVb (Fig. 3f) with $\left([\mathrm{M}+\mathrm{H}]^{+}=m / z\right.$ 728 ) and minor peaks at $m / z 668$ (loss of $60 \mathrm{Da}$; i.e., acetylated $\mathrm{OH}$ group), $\mathrm{m} / \mathrm{z} 626$ (loss of $42 \mathrm{Da}$; i.e., loss of a partial fragment of an acetylated $\mathrm{OH}$ group) and $\mathrm{m} / z 566$ (neutral loss of $60 \mathrm{Da}$ ). In the MS spectrum of IVa, the peak at $\mathrm{m} / \mathrm{z}$
566 is less prominent than in the MS spectrum of regular 3-methyl-aminotriol IVb and the association ion at $\mathrm{m} / \mathrm{z} 788$ $\left([\mathrm{M}+\mathrm{H}+60]^{+}\right)$is absent. Compounds IIIa and IVa have been tentatively assigned as stereoisomers of aminotriol IIIb and 3-methyl-aminotriol IVb, respectively. Unfortunately, the similarity between MS spectra of the respective isomers did not allow discrimination of the stereochemistry of the compounds. The relative abundances of compounds IIIa and IVa of all measured BHPs are 5\% and 16\%, respectively (relative abundance in the HPLC runs for experiments with $M$. alcaliphilum run at standard conditions). However, co-elution of compounds IIIa with aminotetrol $\mathbf{V}$ and compound IVa with 3-methyl-aminotetrol VI complicated the assessment of the peak areas. The production of compounds IIIa and IVa as a consequence of fragmentation in the source of the HPLC-MS from the known aminotriol IIIb and 3-methyl-aminotriol IVb was discarded as two isomers of aminotriol and 3-methyl-aminotriol were also found in HTGC-MS analyses (Fig. 4a). The order of elution on HTGC-MS is reversed compared to HPLC analyses due to measurement on a reversed-phase column on the HPLC-MS.

HTGC-MS analyses of intact BHPs were used to further confirm the presence and possible structure of compounds IIIa and IVa. The tentative identification of aminotriol stereoisomers using HTGC-MS was based on their molecular masses and expected fragmentation patterns from Sessions et al. (2013) and comparison with retention time and mass spectra of aminotriol IIIb from a co-injected extract of Desulfovibrio strain BSS (cf. Blumenberg et al. 2006). The extracted $\mathrm{m} / \mathrm{z} 191$ chromatogram showed two peaks, eluting at slightly different retention times (Fig. 4a), with $\mathbf{M}^{+}$at $m / z, 713$ (Fig. 4b; corresponding to $[\mathrm{M}+\mathrm{H}]^{+}$at $\mathrm{m} / \mathrm{z}$ 714 in HPLC-MS). Diagnostic ions include $m / z 713\left(\mathbf{M}^{+}\right)$, $m / z, 492$ (ring $\mathrm{D}+\mathrm{E}+$ side chain), $m / z, 369$ (ring A-E), $m / z$ 191 (ring A + B), and other fragments representing losses of acetylated groups such as $\mathrm{m} / \mathrm{z} 432$ (492-60), $\mathrm{m} / \mathrm{z} 372$ (492-60×2), $m / z 312(492-60 \times 3)$, and $m / z 653(713-60)$. The full GC-MS spectrum for the novel aminotriol IIIa is not displayed, due to the low concentration of the compound. BHP-656 I and BHP-670 II were not found in HTGC-MS analyses, most likely due to the even lower concentrations of these compounds, since the sensitivity of measurements with HPLC-MS are 50-100\% higher than those measured with GC-MS. This phenomenon is possibly caused by more severe analyte loss during GC-MS analyses (cf. Sessions et al. 2013). Peaks at $m / z 653$ and $m / z 668$ were observed in HTGC-MS analyses and interpreted as degradation products of aminotriol III and 3-methyl-aminotriol IV, when injected on a PTV or split/splitless injector and run on the ZB-5HT column (see Sessions et al. 2013; Eickhoff et al. 2014).

The identification of 3-methylhomologs of aminotriol is based on molecular mass and changes in major MS fragmentation from $\mathrm{m} / \mathrm{z} 191$ to $\mathrm{m} / \mathrm{z} 205$. The $\mathrm{m} / \mathrm{z} 205$ chromatogram 

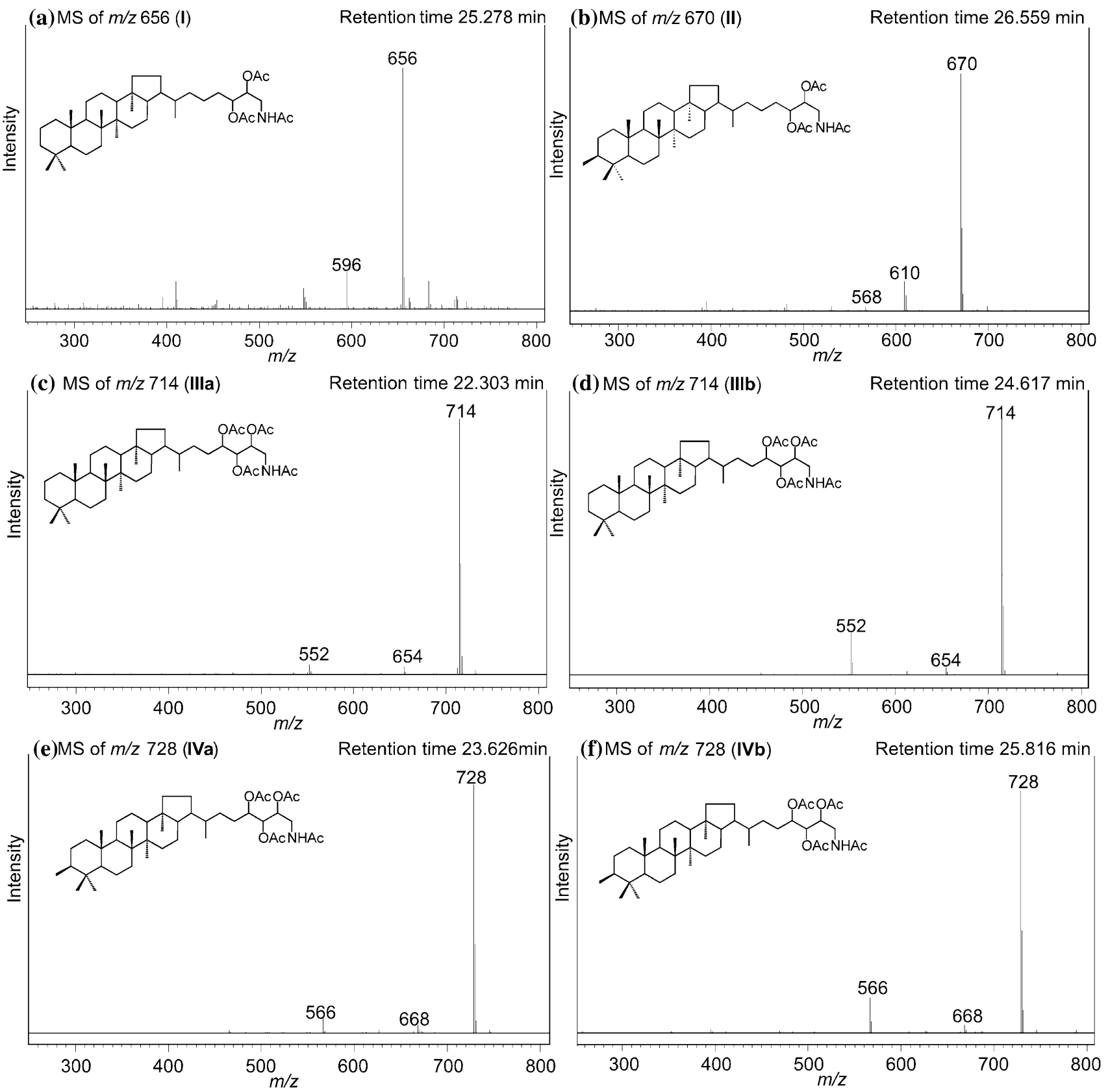

Fig. 3 HPLC-MS spectra of acetylated a aminodiol I, b 3-methyl-aminodiol II, isomers of c, d aminotriol IIIa,b and e, f 3-methyl-aminotriol IVa,b of M. alcaliphilum

showed two peaks, similar as for desmethylated aminotriol (Fig. 4a). The GC-MS spectra of the two stereoisomers of 3-methyl-aminotriol (IVa and IVb) showed fragments characteristic of the hopanoid rings $(\mathrm{m} / \mathrm{z} 205$ and $\mathrm{m} / \mathrm{z} 383$; Fig. 4c, d), and a major peak at $\mathrm{m} / z 492$ (ring D+E+ side chain). Diagnostic fragments resulting from the loss of one or more acetic acid groups, as described above for aminotriol IIIb, were apparent in the mass spectrum of 3-methyl-aminotriols IVa,b $(\mathrm{m} / \mathrm{z} 667,432,372,312)$. The identification of the proposed stereoisomers of aminotriol and 3-methyl-aminotriol in both analyses, HTGC-MS and HPLC-MS, helps to exclude an artificial production of the novel described amino-BHPs. Moreover, HTGC-MS spectra confirmed the structure of aminotriol III and 3-methylaminotriol IV under EI conditions.

The stereochemistry of both identified isomers of aminotriol IIIa,b and 3-methyl-aminotriol IVa,b could not be clarified with HTGC-MS and HPLC-MS either, due to low contents. Typically, the spectra of the biological stereoisomers $17 \beta(\mathrm{H}), 21 \beta(\mathrm{H})$ of common hopanes exhibit a 
(a)

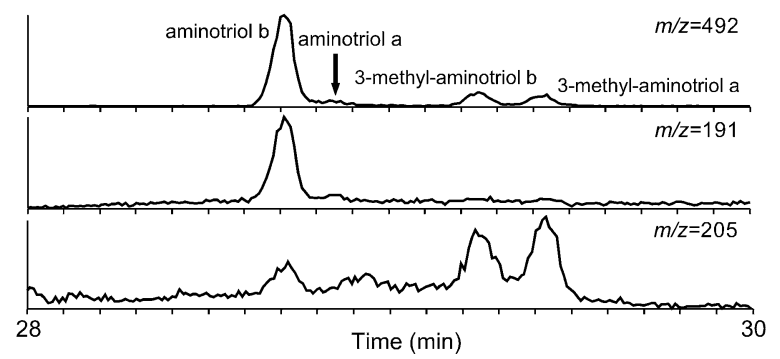

(b)

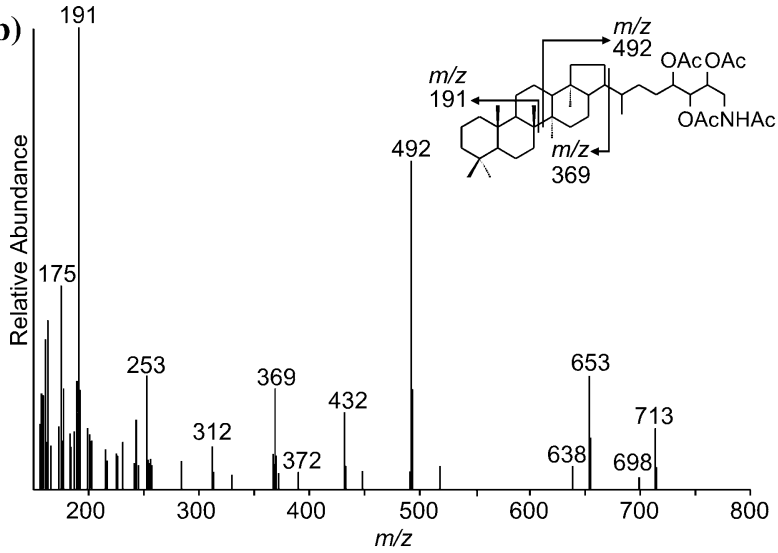

(c)
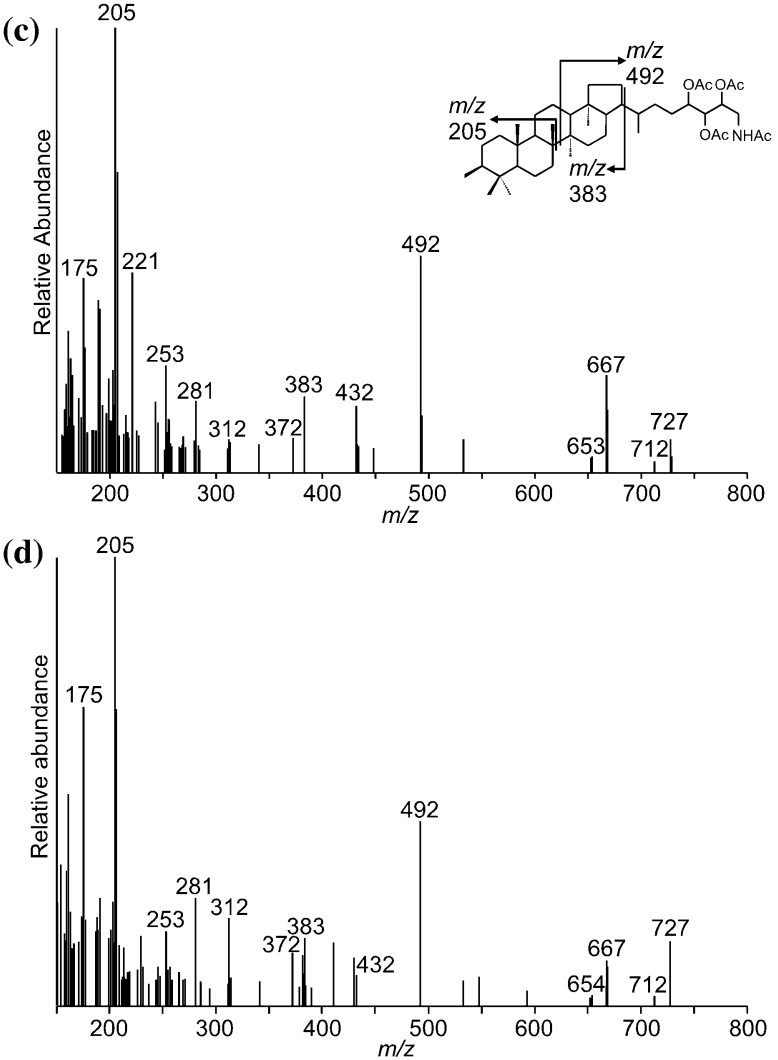

Fig. 4 a HTGC-MS partial chromatograms $(\mathrm{m} / \mathrm{z}$ 492; $\mathrm{m} / \mathrm{z}$ 191; $\mathrm{m} / \mathrm{z}$ 205) of acetylated total lipid extract of $M$. alcaliphilum. b EI mass spectrum of an acetylated isomer of aminotriol b IIIb. c EI mass spectra of acetylated 3-methyl-aminotriol b IVb. d EI mass spectra of acetylated 3-methyl-aminotriol a IVa
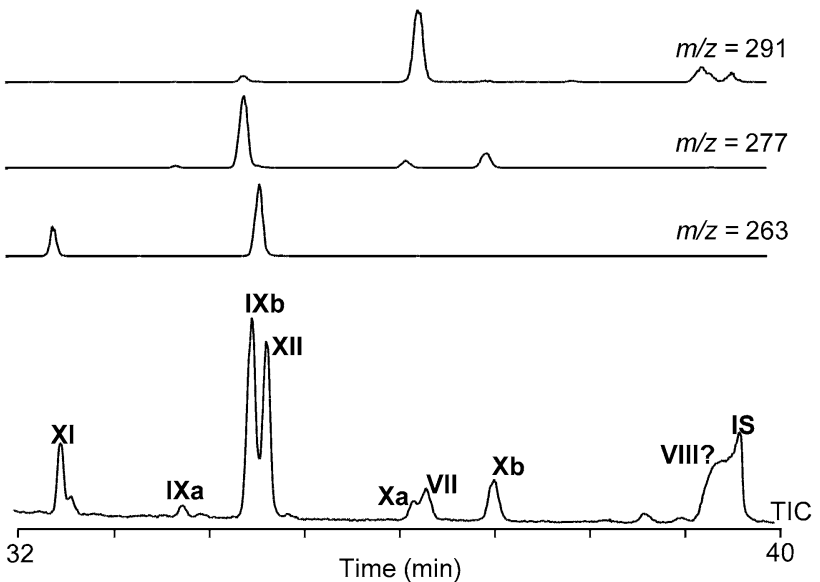

Fig. 5 Partial GC-MS chromatograms $(\mathrm{m} / \mathrm{z}, 291 ; \mathrm{m} / \mathrm{z}, 277 ; \mathrm{m} / \mathrm{z}, 263)$ of hopanol products obtained after periodic acid cleavage. Aminotetrol yielded homohopanol XI, 3-methyl-aminotetrol yielded 3-methylhomohopanol XII, aminotriols yielded bishomohopanols IX, 3-methyl-aminotriols yielded 3-methyl-bishomohopanols $\mathbf{X}$, and aminodiol yielded tentatively identified trishomohopanol VII. VIII $=$ tentatively identified 3-methyl-trishomohopanol (hopanol product of 3-methyl-aminodiol) coeluted with the internal standard (IS)

stronger response for the ring $\mathrm{D}+\mathrm{E}+$ side chain fragment $(\mathrm{m} / \mathrm{z}$ 492) than for the ring $\mathrm{A}+\mathrm{B}$ fragment $(\mathrm{m} / \mathrm{z}, 191$ for aminotriol or $\mathrm{m} / \mathrm{z} 205$ for 3-methyl-aminotriol), although this reasoning does not necessarily extend to all related hopanoids (Peters et al. 2004). In this study, all isomers identified in HTGC-MS showed a ring A + B fragment dominating over the $\mathrm{D}+\mathrm{E}+$ side chain fragment, however, no evidence was found for the presence of isomers with another configuration than the biological $17 \beta(\mathrm{H}), 21 \beta(\mathrm{H})$ stereoisomer.

In the cultures of $M$. alcaliphilum, the two isomers of aminotriol IIIa,b and 3-methyl-aminotriol IVa,b are probably best explained by isomerization at the chiral centers of the side chain. The isomers are most likely C-32 epimers, since the two isomers of aminotriol and two isomers of 3-methyl-aminotriol were present in most samples after periodic acid cleavage (Fig. 5). Periodic acid cleavage of aminotriol produces $\mathrm{C}_{32} 17 \beta(\mathrm{H}), 21 \beta(\mathrm{H})$-hopanol IX (bishomohopanol). Consequently, isomers at positions C-33, C-34, and $\mathrm{C}-35$ would have been lost after cleavage, resulting in one single isomer of $\mathrm{C}_{32} 17 \beta(\mathrm{H}), 21 \beta(\mathrm{H})$-hopanol. The same holds true for 3-methyl-aminotriol. The formation of $\beta \beta$ isomers of aminotriol and methylated homologues (at $\mathrm{C}-2$ position) have been previously described in cultures of the purple non-sulfur bacterium Rhodopseudomonas palustris TIE-1, although only after artificial maturation $\left(170{ }^{\circ} \mathrm{C}, 120 \mathrm{MPa}\right.$; see Eickhoff et al. 2014). In great contrast to the artificial production of isomers in experiments with $R$. palustris TIE1 , the stereoisomers in cultures of M. alcaliphilum were 
produced at optimum temperature and pressure conditions and not as a product of degradation experiments.

The production of BHP isomers in bacteria is common. Isomers of bacteriohopanetetrol (aminotriol equivalent $N$-free BHP) have been previously reported in a variety of bacterial cultures (e.g., Komagataeibacter xylinus, Frankia sp., Methylocella palustris, 'Ca. Brocadia sp.', 'Ca. Scalindua profunda' and 'Ca. Scalindua brodeae'; Rush et al. 2014; Schwartz-Narbonne et al. 2020).

\section{Effect of salinity and nitrate concentration on growth rates}

M. alcaliphilum is a haloalkaliphilic aerobic methanotrophic bacterium belonging to the Type I methanotrophs. M. alcaliphilum strains grow optimally at $\mathrm{NaCl}$ concentration of 3\% (Kalyuzhnaya et al. 2019), and a nitrogen source $\left(\mathrm{KNO}_{3}\right)$ concentration of $10 \mathrm{mM}(0.1 \%)$ is recommended. Here, M. alcaliphilum was grown under four different conditions, standard conditions ( $3 \%$ salinity, $10 \mathrm{mM}$ $\mathrm{KNO}_{3}$ ), high nitrate concentration (100 $\left.\mathrm{mM} \mathrm{KNO}{ }_{3}\right)$, low salinity (1\%) and high salinity (8.7\%). All conditions were chosen arbitrarily considering the range of conditions tolerated by the strain (Kalyuzhnaya et al. 2008). Growth rates (Table 1, Eq. 1) were highest for the experiments with low salinity and high nitrate concentration, while the experiment at high salinity yielded the slowest growth rate. Lag phases (Supplementary figure S1) were also shorter for experiments grown at low salinity, high nitrate concentrations, and standard conditions, while they were longer for the experiment with high salinity, suggesting poor growth or a long period of adaptation to the condition (Tays et al. 2018). Growth rates $(\alpha)$ were calculated from two data points on the growth curve (covering an interval of logarithmic growth) using the formula:

$\alpha=\frac{\ln \left(\frac{N_{T}}{N_{0}}\right)}{\left(t_{T-t_{0}}\right)}$,

where $t$ is time, and $N$ is the cell number (defined by $\mathrm{OD}_{600 \mathrm{~nm}}$ ) at time $t$ (Tays et al. 2018).

Table 1 Growth rates for each condition tested

\begin{tabular}{ll}
\hline Experiment & Growth rate $(1 / \mathrm{h})$ \\
\hline $3 \% \mathrm{NaCl}, 100 \mathrm{mM} \mathrm{KNO}_{3}$ & $3.90 E-02$ \\
$1 \% \mathrm{NaCl}, 10 \mathrm{mM} \mathrm{KNO}_{3}$ & $3.17 E-02$ \\
$8.7 \% \mathrm{NaCl}, 10 \mathrm{mM} \mathrm{KNO}_{3}$ & $1.32 E-02$ \\
$3 \% \mathrm{NaCl}, 10 \mathrm{mM} \mathrm{KNO}_{3}$ & $2.08 E-02$ \\
\hline
\end{tabular}

\section{Effect of salinity and nitrate concentration on the pentacyclic triterpenoid inventory}

Pentacyclic triterpenoids synthesized by $M$. alcaliphilum comprise (3-methyl IV) aminotriol III, (3-methyl VI) aminotetrol $\mathbf{V}$, (3-methyl $\mathbf{X X}$ ) tetrahymanol XIX, and minor amounts of (3-methyl XVIII) diplopterol XVII, (3-methyl XV) diploptene XIII, and (3-methyl XVI) hop-21-ene XIV (Tables 2 and 3; contents of pentacyclic triterpenoids of single experiments are provided in Supplementary File). However, hop-21-ene XIV (and its 3-methylhomologue XVI), as well as other hopenes such as, hop-17(21)-ene, and neohop-13(18)-ene (Eickhoff et al. 2013a), apparently formed by dehydration of diplopterol XVII during injection on the GC-MS via PTV or split/splitless injection and are not produced by the bacteria (Sessions et al. 2013). Given the natural variation typical for culture experiments and

Table 2 Contents of pentacyclic triterpenoids in cultures of $M$. alcaliphilum grown at different salinities

\begin{tabular}{|c|c|c|c|c|}
\hline \multirow[t]{2}{*}{ Compound } & \multicolumn{2}{|c|}{$1 \% \mathrm{NaCl}(n=3)$} & \multicolumn{2}{|c|}{$3 \% \mathrm{NaCl}(n=3)$} \\
\hline & $\begin{array}{l}\text { Content } \\
(\mu g / g \\
d w)\end{array}$ & SD & $\begin{array}{l}\text { Content } \\
(\mu \mathrm{g} / \mathrm{g} \\
\mathrm{dw})\end{array}$ & SD \\
\hline diploptene XIII & 28 & 12 & 21 & 6 \\
\hline hop-21-ene XIV & 16 & 6 & 10 & 3 \\
\hline 3-me-diploptene $\mathbf{X V}$ & 6 & 3 & 5 & 2 \\
\hline 3-me-hop-21-ene XVI & 2 & 0 & 3 & 1 \\
\hline diplopterol XVII & 72 & 39 & 40 & 22 \\
\hline 3-me-diplopterol XVIII & 15 & 1 & 12 & 5 \\
\hline tetrahymanol XIX & 55 & 2 & 50 & 14 \\
\hline 3-me-tetrahymanol XX & 2 & 1 & 4 & 2 \\
\hline aminodiol $\mathbf{I}^{\mathrm{a}}$ & 12 & 4 & 0 & 0 \\
\hline aminotriol a IIIa $^{\mathrm{a}}$ & 9 & 1 & 3 & 5 \\
\hline 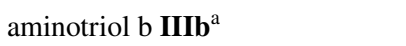 & 420 & 243 & 172 & 34 \\
\hline 3-me-aminotriol a $\mathbf{I V} \mathbf{a}^{\mathrm{a}}$ & 71 & 28 & 8 & 6 \\
\hline 3-me-aminotriol b $\mathbf{I V} \mathbf{b}^{\mathrm{a}}$ & 117 & 70 & 63 & 20 \\
\hline aminotetrol $\mathbf{V}^{\mathrm{a}}$ & 93 & 49 & 40 & 8 \\
\hline 3-me-aminotetrol $\mathbf{V I}^{\mathrm{a}}$ & 127 & 52 & 114 & 26 \\
\hline Sum pentacyclic triterpenoids & 1045 & 413 & 544 & 88 \\
\hline 3-me-diploptene/diploptene & 0.20 & 0.03 & 0.23 & 0.04 \\
\hline 3-me-diplopterol/diplopterol & 0.18 & 0.04 & 0.29 & 0.04 \\
\hline 3-me-tetrahymanol/tetrahymanol & 0.03 & 0.01 & 0.09 & 0.01 \\
\hline 3-me-aminotriol/aminotriol b & 0.28 & 0.04 & 0.37 & 0.04 \\
\hline 3-me-aminotetrol/aminotetrol & 1.35 & 0.49 & 2.87 & 0.13 \\
\hline 3-methylhopanoids/hopanoids & 0.43 & 0.10 & 0.77 & 0.03 \\
\hline
\end{tabular}

${ }^{\mathrm{a} B H P s}$ were measured as products of periodic acid cleavage (aminotetrol yielded homohopanol, aminotriols yielded bishomohopanols, aminodiol yielded trishomohopanol). Bold values show statistically significant difference with respect to standard growing conditions (3\% $\mathrm{NaCl})$ using unpaired $t$ test $(\alpha<0.05) . S D$ standard deviation, $d w$ dry weight 
Table 3 Contents of pentacyclic triterpenoids in cultures of M. alcaliphilum grown with varying amounts of nitrate

\begin{tabular}{|c|c|c|c|c|}
\hline \multirow[t]{2}{*}{ Compound } & \multicolumn{2}{|c|}{$\begin{array}{l}10 \mathrm{mM} \mathrm{KNO} \\
(n=3)\end{array}$} & \multicolumn{2}{|c|}{$\begin{array}{l}100 \mathrm{mM} \mathrm{KNO}_{3} \\
(n=3)\end{array}$} \\
\hline & $\begin{array}{l}\text { Content } \\
(\mu \mathrm{g} / \mathrm{g} \\
\mathrm{dw})\end{array}$ & SD & $\begin{array}{l}\text { Content } \\
(\mu \mathrm{g} / \mathrm{g} \\
\mathrm{dw})\end{array}$ & SD \\
\hline diploptene XIII & 21 & 6 & 18 & 7 \\
\hline hop-21-ene XIV & 10 & 3 & 9 & 3 \\
\hline 3-me-diploptene $\mathbf{X V}$ & 5 & 2 & 8 & 7 \\
\hline 3-me-hop-21-ene XVI & 3 & 1 & 2 & 0 \\
\hline diplopterol XVII & 40 & 22 & 47 & 0 \\
\hline 3-me-diplopterol XVIII & 12 & 5 & 23 & 21 \\
\hline tetrahymanol XIX & 50 & 14 & 136 & 92 \\
\hline 3-me-tetrahymanol XX & 4 & 2 & 19 & 19 \\
\hline aminodiol $\mathbf{I}^{\mathrm{a}}$ & 0 & 0 & $2^{\mathrm{b}}$ & 1 \\
\hline aminotriol a IIIa $^{\text {a }}$ & 3 & 5 & 27 & 14 \\
\hline 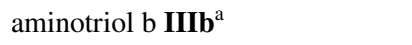 & 172 & 34 & 467 & 159 \\
\hline 3-me-aminotriol a $\mathbf{I V \mathbf { a } ^ { \mathrm { a } }}$ & 8 & 6 & $4^{\mathrm{b}}$ & 2 \\
\hline 3-me-aminotriol b $\mathbf{I V} \mathbf{b}^{\mathrm{a}}$ & 63 & 20 & 140 & 30 \\
\hline aminotetrol $\mathbf{V}^{\mathrm{a}}$ & 40 & 8 & 90 & 69 \\
\hline 3-me-aminotetrol $\mathbf{V} \mathbf{I}^{\mathrm{a}}$ & 114 & 26 & 267 & 200 \\
\hline sum pentacyclic triterpenoids & 544 & 88 & 1239 & 608 \\
\hline 3-me-diploptene/diploptene & 0.23 & 0.04 & 0.43 & 0.25 \\
\hline 3-me-diplopterol/diplopterol & 0.29 & 0.04 & 0.49 & 0.36 \\
\hline 3-me-tetrahymanol/tetrahymanol & 0.09 & 0.01 & 0.14 & 0.05 \\
\hline 3-me-aminotriol/aminotriol b & 0.37 & 0.04 & 0.30 & 0.05 \\
\hline 3-me-aminotetrol/aminotetrol & 2.87 & 0.13 & 2.97 & 0.14 \\
\hline 3-methyhopanoids/hopanoids & 0.77 & 0.03 & 0.87 & 0.11 \\
\hline
\end{tabular}

${ }^{a}$ BHPs were measured as products of periodic acid cleavage (aminotetrol yielded homohopanol, aminotriols yielded bishomohopanols, aminodiol yielded trishomohopanol). Bold numbers indicate statistically significant differences to standard growth conditions $(10 \mathrm{mM}$ $\left.\mathrm{KNO}_{3}\right)$ using unpaired $t$ test $(\alpha<0.05)$. $S D$ standard deviation, $d w$ dry weight

${ }^{\mathrm{b}}$ Average of 2 samples

the fact that the experiments of this study were prepared from different batches of freshly prepared starter cultures, a certain variability in the data is to be expected. Still, the standard deviation for some of the compounds is too high, precluding a meaningful comparison. Furthermore, cell numbers $\left(\mathrm{OD}_{600}\right)$ were determined for one replicate under each culture condition only; it is therefore possibly that samples were harvested during different growth phases.

For consistency with the section 'Novel N-containing BHPs', BHPs are referred to by the name of the intact compounds, even if the reported contents correspond to the measurement of hopanol cleavage products (see also "Materials and methods" section). The periodic acid cleavage procedure yielded $\mathrm{C}_{32} 17 \beta(\mathrm{H}), 21 \beta(\mathrm{H})$-hopanol (bishomohopanol IX) from tetrafunctionalized BHPs and
$\mathrm{C}_{31} 17 \beta(\mathrm{H}), 21 \beta(\mathrm{H})$-hopanol (homohopanol XI) from pentafunctionalized BHPs. Since the only tetrafunctionalized and pentafunctionalized BHPs produced by $M$. alcaliphilum are aminotriol III and aminotetrol $\mathbf{V}$, respectively, the bishomohopanol IX and homohopanol XI (and their respective methyl homologues) derived exclusively from these compounds (Fig. 5). Minor amounts of $17 \beta(\mathrm{H}), 21 \beta(\mathrm{H})-33-$ hopanol (trishomohopanol VII) in samples grown at high nitrate and low salinity are interpreted as cleavage product of aminodiol (BHP-560 I).

In experiments at different salinities, the total amount of pentacyclic triterpenoids decreased with increasing salinity (Fig. 6a; Table 2), suggesting that hopanoid production in M. alcaliphilum is higher at lower salinities. The overall contents of pentacyclic triterpenoids produced at $8.7 \%$ $\mathrm{NaCl}$ (maximum salinity tolerance, Kalyuzhnaya et al. 2008) could not be determined since contents were too low (no measurements on the GC-FID were possible). However, measurement of BHPs on the HPLC-MS (Fig. 1) revealed that under high salinity conditions M. alcaliphilum produced less hopanoids than under standard $(3 \%)$ and low salinity (1\%) conditions. Experiments at $8.7 \% \mathrm{NaCl}$ also gave the slowest growth rates (Table 1), indicating reduced activity of M. alcaliphilum under such conditions. Reduced activity of M. alcaliphilum at higher salinity is consistent with experiments performed by Sherry et al. (2016) on sediments from the River Tyne estuary, UK, hosting a diverse community of methanotrophic bacteria, where methanotrophic activity and methane oxidation rates decreased with increasing salinity.

In our experiments, most hopanoids were produced at the lowest salinity ( $1 \% \mathrm{NaCl}$; Fig. 6 ), with the highest contents of aminotriols IIIa,b and the corresponding 3-methylhomologues IVa,b (Fig. 6c), and 3-methyl-aminotetrol VI, and tetrahymanol XIX with lowest contents (Fig. 6b, f). According to statistical analysis (unpaired $t$ test; $p$ values from $t$ tests are provided in Supplementary File), only 3-methylaminotriol a IIIa varied significantly between different culture conditions. More relevant than changes of the absolute content of a specific hopanoid are changes of the proportion of this molecule to the considered class of compounds at varying salinities (Fig. 7); i.e., the relative abundance of a compound. The relative abundances of $\mathrm{C}_{30}$ hopanoids and $\mathrm{C}_{30}$ hopanols were similar under the two conditions tested. Tetrahymanol XIX showed an increase of $4 \%$ in experiments with $3 \% \mathrm{NaCl}$, while the proportion of BHPs decreased by $3 \%$. Tetrahymanol - and its degradation product gammacerane-are commonly used as biomarkers for stratification of the water column; these compounds were also suggested to indicate hypersaline conditions in stratified water bodies (Sinninghe Damsté et al. 1995; Peters et al. 2004; Banta et al. 2015). Our results confirm that an increase of salinity indeed favors the synthesis of tetrahymanol XIX at the expense of hopanoids. Even though aerobic methanotrophic 

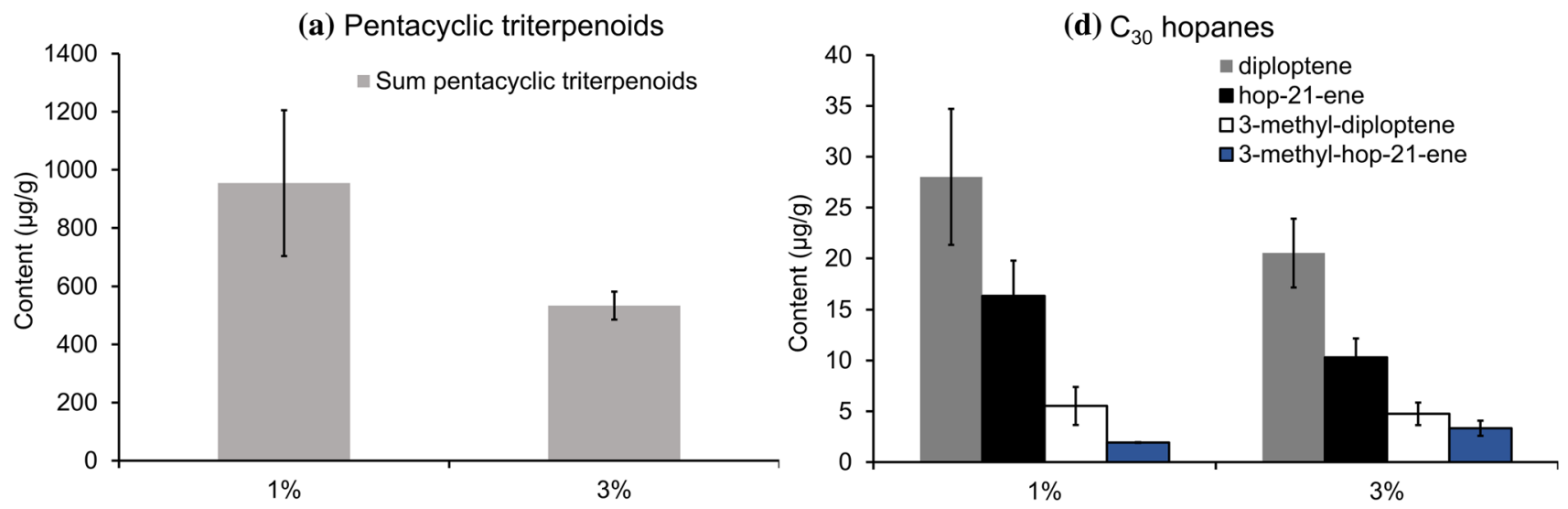

(b) Aminotetrol
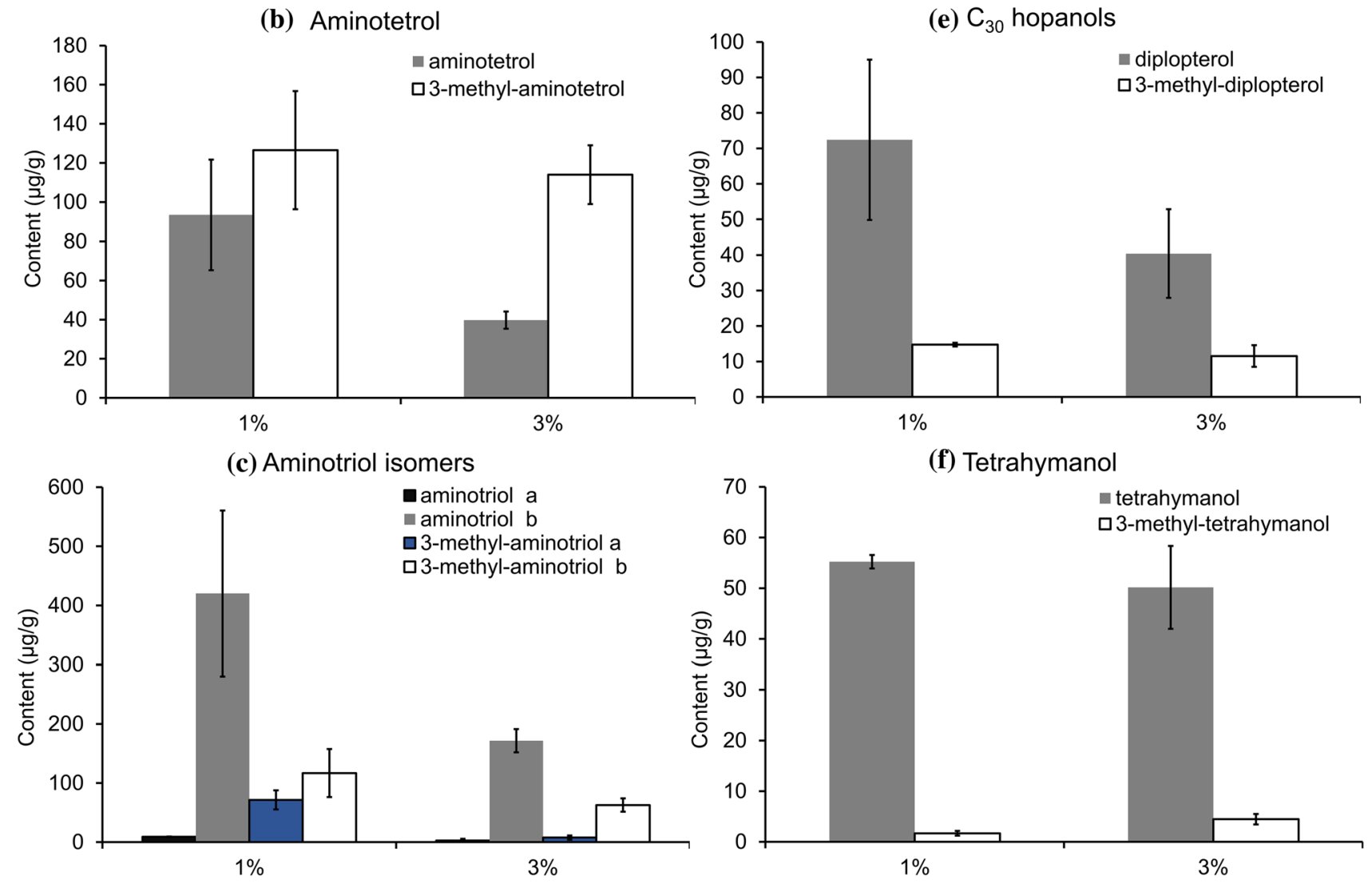

Fig. 6 Distribution of pentacyclic triterpenoids in response to variations in salinity (1\% and 3\%): a total pentacyclic triterpenoids, $\mathbf{b}$ aminotetrol, $\mathbf{c}$ aminotriol isomers, $\mathbf{d ~} \mathrm{C}_{30}$ hopanes, e $\mathrm{C}_{30}$ hopanols, $\mathbf{f}$ tetrahymanol. BHPs were measured as products of periodic acid

cleavage (aminotetrol yielded homohopanol, aminotriols yielded bishomohopanols). Error bars represent standard errors for $n=3$ replicates

bacteria are not the only known producers of tetrahymanol (Rashby et al. 2007; Eickhoff et al. 2013b; Werne et al. 2002), all tetrahymanol producers seem to have in common that they live at oxic-anoxic interfaces or high salinities.

The results of this study indicate that low salinities favor the formation of BHPs (Fig. 7), especially the formation of the regular aminotriol $\mathrm{b}$ IIIb, which showed a relative increase of $10 \%$ at $1 \% \mathrm{NaCl}$. Interestingly, 3-methyl-aminotetrol VI, which is among the most specific biomarkers of aerobic methanotrophic bacteria (Talbot et al. 2014), showed a relative increase of $7 \%$ in the $3 \% \mathrm{NaCl}$ experiments, consistent with an increase of the 3-methyl to desmethylated 
Fig. 7 Relative abundance in percent of main pentacyclic triterpenoids of $M$. alcaliphilum in response to variations in salinity (1\% and $3 \%)$. BHPs were measured as products of periodic acid cleavage (aminotetrol yielded homohopanol, aminotriol yielded bishomohopanol). Novel compounds (aminodiol, aminotriol a, and 3-methyl-aminotriol a) were excluded from calculations due to low contents

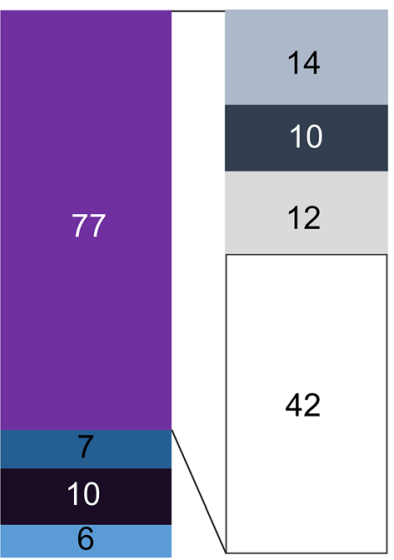

$1 \%$

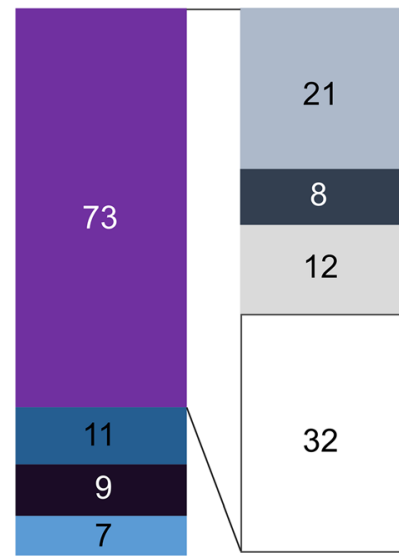

$3 \%$
$\mathrm{C}_{30}$ hopanes

- $\mathrm{C}_{30}$ hopanols

- tetrahymanol

- BHPs

-aminotriol b

3-methyl-aminotriol b

- aminotetrol

3-methyl-aminotetrol homologues ratio at $3 \%$ salinity (Table 2). Such increased production of 3-methyl compounds is possibly an adaptive response to more extreme conditions since 3-methylhopanoids were shown to play an important role in maintaining the cell membrane integrity under unfavorable conditions in mesocosm experiments (Osborne et al. 2017).

In experiments with high nitrate level, the total contents of pentacyclic triterpenoids increased (Fig. 8a; Table 3). Particularly BHP contents increased (Fig. 8b, c), especially the aminotriol isomers IIIa and $\mathbf{b}$, as well as 3-methyl-aminotriol b IVb (Fig. 8c). Contents of these compounds were more than doubled compared to standard culture conditions (Table 3, unpaired $t$ test; $p$ values from $t$ tests provided in Supplementary File). For some compounds (namely hopanoids, hopanols, tetrahymanol, and aminotetrol), the standard deviation is unfortunately too high-even considering the natural variability typically associated to culture experiments- to make robust interpretations regarding the behavior of these lipids at different nitrate concentrations.

Considering the relative percentages of compounds, all BHPs showed an increase of 7\%, regular aminotriol b IIIb increased by $8 \%$, while relative contents of aminotetrol V, 3-methyl-aminotetrol VI, and 3-methyl-aminotriol b IVb remained similar at higher nitrate concentrations (not shown). This may suggest that higher BHP contents at higher nitrate concentration are especially related to increased production of aminotriol. To date, few studies have been undertaken to understand the role of nitrate in hopanoid production, specifically in hopanoid-producing bacteria capable of nitrogen fixation (Frankia sp., Nalin et al. 2000; Nostoc punctiforme, Doughty et al. 2009; Desulfovibrio bastinii, Blumenberg et al. 2012). For instance, experiments with strains of Frankia $s p$., under nitrogenenriched $\left(\mathrm{NH}_{4}^{+}\right)$and nitrogen-depleted (nitrogen fixation) conditions, revealed that BHP contents in most of the strains were slightly higher under nitrogen-enriched conditions (Nalin et al. 2000). In the cyanobacterium N. punctiforme, nitrogen limitation enhanced BHP production as a survival mechanism during the first 2 weeks of incubation, returning afterwards to the starting levels encountered during standard conditions (Doughty et al. 2009). A similar study with the sulfate-reducing bacterium $D$. bastinii, grown with $\mathrm{NH}_{4}{ }^{+}$or $\mathrm{N}_{2}$ as sole nitrogen source, found that nitrogen conditions do not much affect hopanoid composition, although the growth yield was higher with $\mathrm{NH}_{4}$ as nitrogen source (Blumenberg et al. 2012). The conflicting results of these studies argue against a direct link between hopanoid production and nitrogen uptake. Instead, hopanoid production is more likely related to physiological processes reflecting adaptation. Although we are only able to use some of the data of the nitrate experiments for a statistically sound comparison, the results of this study are in line with some of the earlier studies, documenting a strong positive response in BHP production to increased nitrate concentrations.

The ratio of 3-methyl to desmethyl homologues tended to increase slightly in high nitrate experiments too. This applies to $\mathrm{C}_{30}$ hopanoids, tetrahymanol, and aminotetrol as well, but this ratio decreased for aminotriol $b$ (Table 2). The effect of the culture conditions on hopanoid methylation seems to have been a minor variable under the chosen conditions, although it has been shown that the degree of methylation influences membrane stability as well (Doughty et al. 2009; Welander et al. 2009). Future experiments on the factors governing lipid production by aerobic methanotrophs should expand the range of environmental conditions to better constrain the patterns in the response of methanotrophs to changing conditions. 
(a) Total pentacyclic triterpenoids

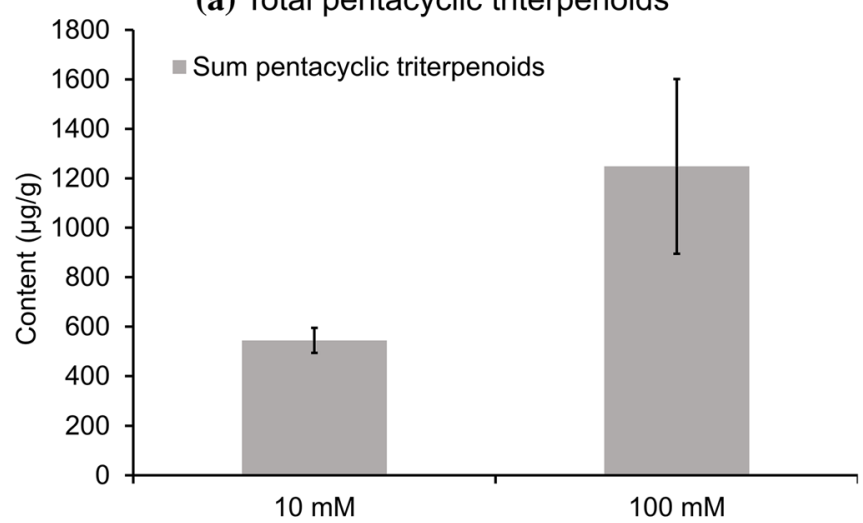

(b) Aminotetrol

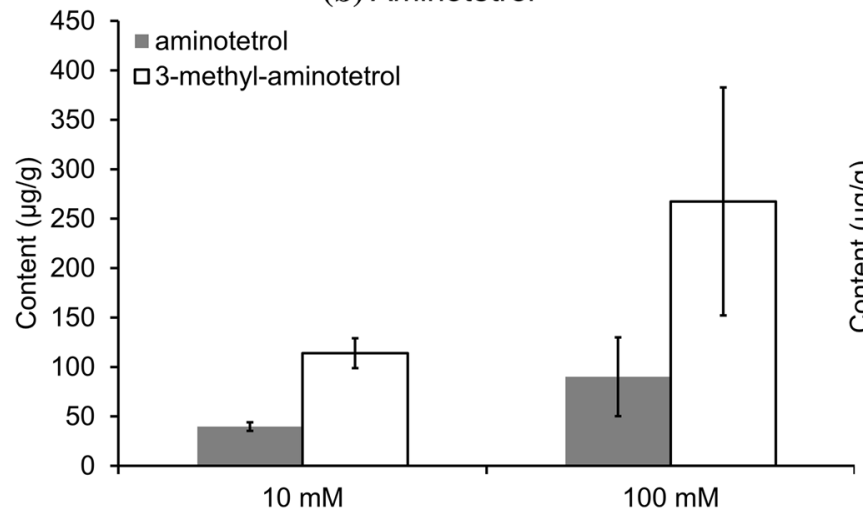

(c) Aminotriol isomers

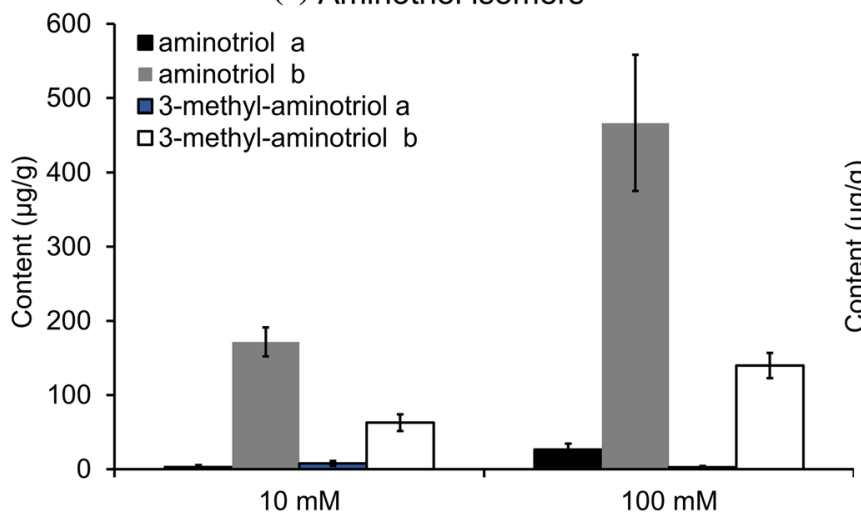

Fig. 8 Distribution of pentacyclic triterpenoids in response to variations in nitrate concentration $(10 \mathrm{mM}$ and $100 \mathrm{mM})$ : a total pentacyclic triterpenoids, $\mathbf{b}$ aminotetrol, $\mathbf{c}$ aminotriol isomers, $\mathbf{d ~} \mathrm{C}_{30}$ hopanoids, e $\mathrm{C}_{30}$ hopanols, $\mathbf{f}$ tetrahymanol. BHPs were measured

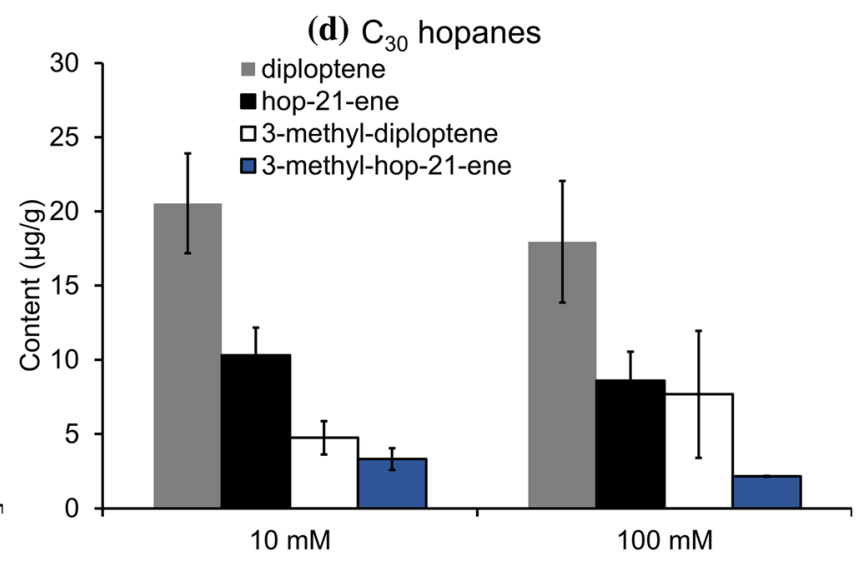

(e) $\mathrm{C}_{30}$ hopanols

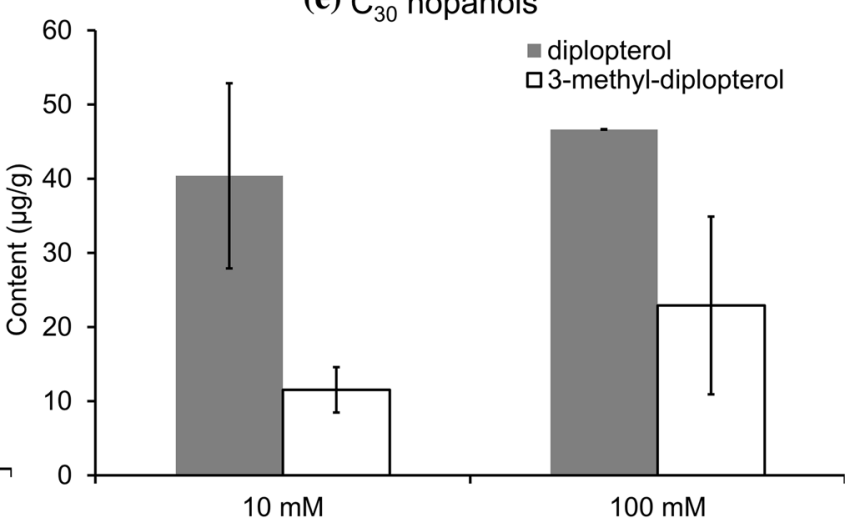

(f) Tetrahymanol

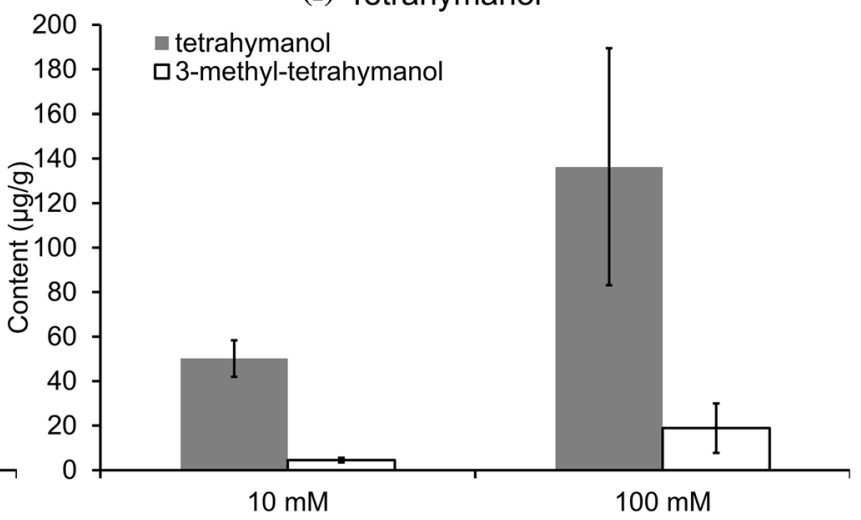

as products of periodic acid cleavage (aminotetrol yielded homohopanol, aminotriols yielded bishomohopanols). Error bars represent standard errors for $n=3$ replicates per condition

M. alcaliphilum strains revealed higher growth rates and shorter lag phases at lower salinity $(1 \% \mathrm{NaCl})$ and higher nitrate concentration $(100 \mathrm{mM})$. Our results also demonstrate an effect of salinity and nitrate concentration on the abundance and composition of pentacyclic triterpenoids. Hopanoid abundance was found to be higher in low salinity experiments $(1 \% \mathrm{NaCl})$. Likewise, low salinity settings 
favored the production of BHPs, especially that of regular aminotriol $\mathrm{b}$, while higher salinity $(3 \% \mathrm{NaCl})$ favored the synthesis of tetrahymanol and 3-methyl-aminotetrol. Production of 3-methyl compounds was favored at higher salinity as well, reflected in an increase in the ratio of methylated to desmethylated compounds. In experiments with varying nitrate concentrations, higher concentrations correlated with more production of BHPs (aminotriol and 3-methyl-aminotriol).

\section{Appendix}

See Fig. 9.<smiles>[R]C1CCC2(C)C(CCC3C4CCC(C(C)CCCC(O)C(O)CN)C4CCC32C)C1(C)I(P=C)[PH](=P)I</smiles><smiles>[R]C1CCC2(C)C(CCC3C4CCC(C(C)CCC(O)C(O)C(O)CN)C4CCC32C)C(C)(C#N)C1(C)[PH](=C)P</smiles>

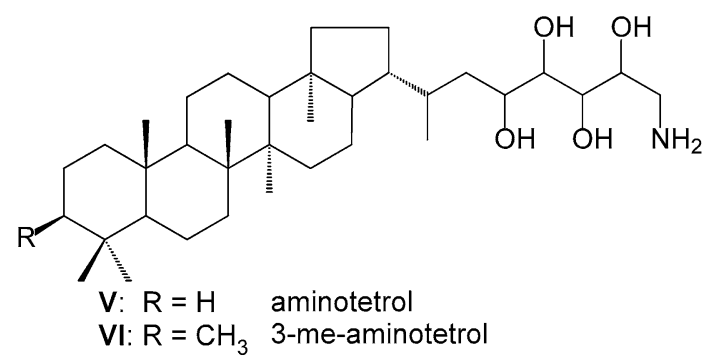<smiles>[R]CC1(C)CCC2(C)C3CCC4C5CCC(C(C)CCCCO)C5CCC4(C)C3CCC2(C)C1(C)C#P</smiles><smiles>[R]CC1(C[Y])C([R])CCC2(C)C3CCC4C5(C)CCC(C(C)CCCO)C5CCC4(C)C3CCC21C=PC</smiles><smiles>[R]C1CCC2(C)C(CCC3C4(C)CCC5C(C(C)CCO)CCC5C4(C)CCC32C)C1([Y4])[R]#C</smiles><smiles>[R]C1CCC2(C)C(CCC3(C)C(C)CCC45C(C(=C)C)CCC4C5CCC32)C1([Y4]#[X])[R]#C</smiles>

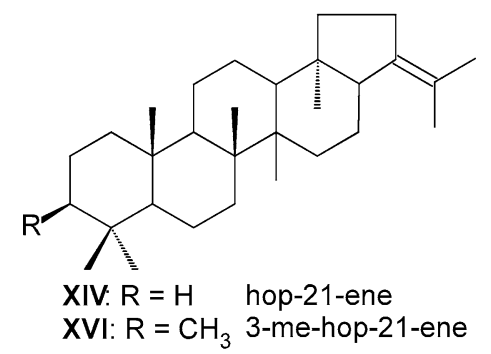

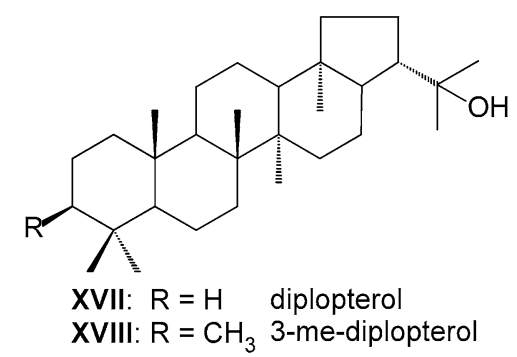<smiles>[X][X]C1([R]([R])=C)C([R])CCC2(C)C1CCC1(C)C2CCC2C3CCC(O)CC3CCC21C</smiles> 
Supplementary Information The online version contains supplementary material available at https://doi.org/10.1007/s00792-021-01228-x.

Acknowledgements We thank Sabine Beckmann (Universität Hamburg) for assistance in sample preparation and measurements and Lars Grimm (Universität Tübingen) for assistance in cultivation. Alexmar Cordova-Gonzalez was supported by a doctoral fellowship of the German Academic Exchange Service-DAAD. We thank two anonymous reviewers and the associate editor for insightful comments and suggestions.

Funding Open Access funding enabled and organized by Projekt DEAL.

Open Access This article is licensed under a Creative Commons Attribution 4.0 International License, which permits use, sharing, adaptation, distribution and reproduction in any medium or format, as long as you give appropriate credit to the original author(s) and the source, provide a link to the Creative Commons licence, and indicate if changes were made. The images or other third party material in this article are included in the article's Creative Commons licence, unless indicated otherwise in a credit line to the material. If material is not included in the article's Creative Commons licence and your intended use is not permitted by statutory regulation or exceeds the permitted use, you will need to obtain permission directly from the copyright holder. To view a copy of this licence, visit http://creativecommons.org/licenses/by/4.0/.

\section{References}

Bale NJ, Rijpstra WIC, Sahonero-Canavesi DX, Oshkin IY, Belova SE, Dedysh SN, Sinninghe Damsté JS (2019) Fatty acid and hopanoid adaption to cold in the methanotroph Methylovulum psychrotolerans. Front Microbiol. https://doi.org/10.3389/fmicb.2019.00589 (article 589)

Banta AB, Wei JH, Welander PV (2015) A distinct pathway for tetrahymanol synthesis in bacteria. Proc Natl Acad Sci USA 112:13478-13483

Bessette S, Moalic Y, Gautey S, Lesongeur F, Godfroy A, Toffin L (2017) Relative abundance and diversity of bacterial methanotrophs at the oxic-anoxic interface of the Congo Deep-Sea Fan. Front Microbiol. https://doi.org/10.3389/fmicb.2017.00715 (article 715)

Blumenberg M, Krüger M, Nauhaus K, Talbot HM, Oppermann BI, Seifert R, Pape T, Michaelis W (2006) Biosynthesis of hopanoids by sulfate-reducing bacteria (genus Desulfovibrio). Environ Microbiol 8:1220-1227

Blumenberg M, Hoppert M, Krüger M, Dreier A, Thiel V (2012) Novel findings on hopanoid occurrences among sulfate reducing bacteria: is there a direct link to nitrogen fixation? Org Geochem 49:1-5

Bodelier PLE, Laanbroek HJ (2004) Nitrogen as a regulatory factor of methane oxidation in soils and sediments. FEMS Microbiol Ecol 47:265-277

Bodelier PLE, Roslev P, Henckel T, Frenzel P (2000) Stimulation by ammonium-based fertilizers of methane oxidation in soil around rice roots. Nature 403:421-424

Boetius A, Wenzhöfer F (2013) Seafloor oxygen consumption fueled by methane from cold seeps. Nat Geosci 6:725-734

Bouvier P, Rohmer M, Benveniste P, Ourisson G (1976) $\Delta^{8(14)}$-steroids in the bacterium Methylococcus capsulatus. Biochemistry Journal 159:267-271

Bowman JP (2006) The methanotrophs-the families Methylococcaceae and Methylocystaceae. In: Dworkin M, Falkow S,
Rosenberg E, Schleifer K-H, Stackebrandt E (eds) The Prokaryotes. Springer, New York, pp 266-289

Bowman JP, Sly LI, Nichols PD, Hayward AC (1993) Revised taxonomy of the methanotrophs: description of Methylobacter gen. nov., emendation of Methylococcus, validation of Methylosinus and Methylocystis species, and a proposal that the family Methylococcaceae includes only the group I methanotrophs. Int J Syst Evol Microbiol 43:735-753

Cordova-Gonzalez A, Birgel D, Kappler A, Peckmann J (2020) Carbon stable isotope patterns of cyclic terpenoids: a comparison of cultured alkaliphilic aerobic methanotrophic bacteria and methaneseep environments. Org Geochem. https://doi.org/10.1016/j.orgge ochem.2019.103940 (article 103940)

Doughty DM, Hunter RC, Summons RE, Newman DK (2009) 2-Methylhopanoids are maximally produced in akinetes of Nostoc punctiforme: geobiological implications. Geobiology 7:524-532

Dunfield P, Knowles R (1995) Kinetics of inhibition of methane oxidation by nitrate, nitrite, and ammonium in a humisol. Appl Environ Microbiol 61:3129-3135

Eickhoff M, Birgel D, Talbot HM, Peckmann J, Kappler A (2013a) Bacteriohopanoid inventory of Geobacter sulfurreducens and Geobacter metallireducens. Org Geochem 58:107-114

Eickhoff M, Birgel D, Talbot HM, Peckmann J, Kappler A (2013b) Oxidation of $\mathrm{Fe}$ (II) leads to increased C-2 methylation of pentacyclic triterpenoids in the anoxygenic phototrophic bacterium Rhodopseudomonas palustris strain TIE-1. Geobiology 11:268-278

Eickhoff M, Birgel D, Talbot HM, Peckmann J, Kappler A (2014) Diagenetic degradation products of bacteriohopanepolyols produced by Rhodopseudomonas palustris strain TIE-1. Org Geochem 68:31-38

Hanson RS, Hanson TE (1996) Methanotrophic bacteria. Microbiol Rev 60:439-471

Hoefman S, van der Ha D, Boon N, Vandamme P, De Vos P, Heylen K (2014) Niche differentiation in nitrogen metabolism among methanotrophs within an operational taxonomic unit. BMC Microbiol. https://doi.org/10.1186/1471-2180-14-83 (article 83)

Jahnke LL, Summons RE, Hope JM, des Marais DJ (1999) Carbon isotopic fractionation in lipids from methanotrophic bacteria II: the effects of physiology and environmental parameters on the biosynthesis and isotopic signatures of biomarkers. Geochim Cosmochim Acta 63:79-93

Jorgensen AD, Picel KC, Stamoudis VC (1990) Prediction of gas chromatography flame ionization detector response factors from molecular structures. Anal Chem 62:683-689

Kalyuzhnaya MG, Khmelenina V, Eshinimaev B, Sorokin D, Fuse H, Lidstrom M, Trotsenko Y (2008) Classification of halo(alkali) philic and halo(alkali)tolerant methanotrophs provisionally assigned to the genera Methylomicrobium and Methylobacter and emended description of the genus Methylomicrobium. Int J Syst Evol Microbiol 58:591-596

Kalyuzhnaya MG, Gomez OA, Murrell JC (2019) The methane-oxidizing bacteria (methanotrophs). In: McGenity TJ (ed) Taxonomy, genomics and ecophysiology of hydrocarbon-degrading microbes. Handbook of hydrocarbon and lipid microbiology. Springer, Cham, pp 245-278

Kannenberg EL, Poralla K (1999) Hopanoid biosynthesis and function in bacteria. Naturwissenschaften $86: 168-176$

Knief C (2015) Diversity and habitat preferences of cultivated and uncultivated aerobic methanotrophic bacteria evaluated based on pmoA as molecular marker. Front Microbiol. https://doi.org/10. 3389/fmicb.2015.01346 (article 1346)

Kulkarni G, Wu C-H, Newman DK (2013) The general stress response ractor EcfG regulates expression of the C-2 hopanoid methylase $\mathrm{HpnP}$ in Rhodopseudomonas palustris TIE-1. J Bacteriol 195:2490-2498 
Nalin R, Putra SR, Domenach A-M, Rohmer M, Gourbiere F, Berry AM (2000) High hopanoid/total lipids ratio in Frankia mycelia is not related to the nitrogen status. Microbiology 146:3013-3019

Noll M, Frenzel P, Conrad R (2008) Selective stimulation of type I methanotrophs in a rice paddy soil by urea fertilization revealed by RNA-based stable isotope probing. FEMS Microbiol Ecol 65:125-132

Nyerges G, Stein LY (2009) Ammonia cometabolism and product inhibition vary considerably among species of methanotrophic bacteria. FEMS Microbiol Lett 297:131-136

Nyerges G, Han S-K, Stein LY (2010) Effects of ammonium and nitrite on growth and competitive fitness of cultivated methanotrophic bacteria. Appl Environ Microbiol 76(16):5648-5651 (article 5648)

Orata FD, Meier-Kolthoff JP, Sauvageau D, Stein LY (2018) Phylogenomic analysis of the gammaproteobacterial methanotrophs (order Methylococcales) calls for the reclassification of members at the genus and species levels. Front Microbiol. https://doi.org/ 10.3389/fmicb.2018.03162 (article 3162)

Osborne KA, Gray ND, Sherry A, Leary P, Mejeha O, Bischoff J, Rush D, Sidgwick FR, Birgel D, Kalyuzhnaya MG, Talbot HM (2017) Methanotroph-derived bacteriohopanepolyol signatures as a function of temperature related growth, survival, cell death and preservation in the geological record. Environ Microbiol Rep 9:492-500

Peters K, Walters CC, Moldowan JM (2004) The biomarker guide, volume 2: biomarkers and isotopes in petroleum systems and earth history, 2nd edn. Cambridge University Press, Cambridge

Poralla K, Härtner T, Kannenberg E (1984) Effect of temperature and $\mathrm{pH}$ on the hopanoid content of Bacillus acidocaldarius. FEMS Microbiol Lett 23:253-256

Rashby SE, Sessions AL, Summons RE, Newman DK (2007) Biosynthesis of 2-methylbacteriohopanepolyols by an anoxygenic phototroph. Proc Natl Acad Sci USA 104:15099-15104

Rohmer M, Bouvier-Navé P, Ourisson G (1984) Distribution of hopanoid triterpenes in prokaryotes. J Gen Microbiol 130:1137-1150

Rush D, Osborne KA, Birgel D, Kappler A, Hirayama H, Peckmann J, Poulton SW, Nickel JC, Mangelsdorf K, Kalyuzhnaya MG, Sidgwick FR, Talbot HM (2016) The bacteriohopanepolyol inventory of novel aerobic methane oxidising bacteria reveals new biomarker signatures of aerobic methanotrophy in marine systems. PLoS ONE 11:e0165635

Schwartz-Narbonne R, Schaeffer P, Hopmans EC, Schenesse M, Charlton EA, Jones DM, Sinninghe Damsté JS, Haque MFU, Jetten MSM, Lengger SK, Murrell JC, Normand P, Nuijten GHL, Talbot HM, Rush D (2020) A unique bacteriohopanetetrol stereoisomer of marine anammox. Org Geochem 143:103994

Semrau JD, DiSpirito AA, Yoon S (2010) Methanotrophs and copper. FEMS Microbiol Rev 34:496-531

Sessions AL, Zhang L, Welander PV, Doughty D, Summons RE, Newman DK (2013) Identification and quantification of polyfunctionalized hopanoids by high temperature gas chromatography-mass spectrometry. Org Geochem 56:120-130

Sherry A, Osborne KA, Sidgwick FR, Gray ND, Talbot HM (2016) A temperate river estuary is a sink for methanotrophs adapted to extremes of $\mathrm{pH}$, temperature and salinity. Environ Microbiol Rep $8: 122-131$

Rush D, Sinninghe Damsté JS, Poulton SW, Thamdrup B, Garside AL, Acuña González J, Schouten S, Jetten MSM, Talbot HM (2014)
Anaerobic ammonium-oxidising bacteria: a biological source of the bacteriohopanetetrol stereoisomer in marine sediments. Geochim Cosmochim Acta 140:50-64

Sinninghe Damsté JS, Kenig F, Koopmans MP, Köster J, Schouten S, Hayes JM, de Leeuw JW (1995) Evidence for gammacerane as an indicator of water column stratification. Geochim Cosmochim Acta 59:1895-1900

Talbot HM, Farrimond P (2007) Bacterial populations recorded in diverse sedimentary biohopanoid distributions. Org Geochem 38:1212-1225

Talbot HM, Watson DF, Murrell JC, Carter JF, Farrimond P (2001) Analysis of intact bacteriohopanepolyols from methanotrophic bacteria by reversed-phase high-performance liquid chromatography-atmospheric pressure chemical ionisation mass spectrometry. J Chromatogr A 921:175-185

Talbot HM, Watson DF, Pearson EJ, Farrimond P (2003) Diverse biohopanoid compositions of non-marine sediments. Org Geochem 34:1353-1371

Talbot HM, Handley L, Spencer-Jones CL, Dinga BJ, Schefuss E, Mann PJ, Poulsen JR, Spencer RGM, Wabakanghanzi JN, Wagner $\mathrm{T}$ (2014) Variability in aerobic methane oxidation over the past 1.2 Myrs recorded in microbial biomarker signatures from Congo fan sediments. Geochim Cosmochim Acta 133:387-401

Talbot HM, Bischoff J, Inglis GN, Collinson ME, Pancost RD (2016) Polyfunctionalised bio- and geohopanoids in the Eocene Cobham Lignite. Org Geochem 96:77-92

Tays C, Guarnieri MT, Sauvageau D, Stein LY (2018) Combined effects of carbon and nitrogen source to optimize growth of proteobacterial methanotrophs. Front Microbiol. https://doi.org/10. 3389/fmicb.2018.02239 (article 2239)

van Winden JF (2011) Methane cycling in peat bogs: environmental relevance of methanotrophs revealed by microbial lipid chemistry. $\mathrm{PhD}$ Thesis. Utrecht University

Wei JH, Yin XC, Welander PV (2016) Sterol synthesis in diverse bacteria. Front Microbiol. https://doi.org/10.3389/fmicb.2016.00990 (article 990)

Welander PV, Summons RE (2012) Discovery, taxonomic distribution, and phenotypic characterization of a gene required for 3-methylhopanoid production. Proc Natl Acad Sci USA 109:12905-12910

Welander PV, Hunter RC, Zhang LC, Sessions AL, Summons RE, Newman DK (2009) Hopanoids play a role in membrane integrity and $\mathrm{pH}$ homeostasis in Rhodopseudomonas palustris TIE-1. J Bacteriol 191:6145-6156

Werne JP, Baas M, Sinninghe Damsté JS (2002) Molecular isotopic tracing of carbon flow and trophic relationships in a methanesupported benthic microbial community. Limnol Oceanogr 47:1694-1701

Zundel M, Rohmer M (1985) Prokaryotic triterpenoids. 1. 3-betamethylhopanoids from Acetobacter species and Methylococcus capsulatus. Eur J Biochem 150:23-27

Publisher's Note Springer Nature remains neutral with regard to jurisdictional claims in published maps and institutional affiliations. 